\title{
Temporal Changes of the Endothelin System in Human Cytotrophoblasts During the First Trimester of Pregnancy
}

\author{
A. MAJALI-MARTINEZ ${ }^{1}$, S. BARTH ${ }^{1,2}$, U. LANG ${ }^{1}$, G. DESOYE ${ }^{1}$, M. CERVAR-ZIVKOVIC ${ }^{1}$ \\ ${ }^{1}$ Department of Obstetrics and Gynecology, Medical University of Graz, Graz, Austria, \\ ${ }^{2}$ Department of Biochemistry and Molecular Biology, Medical University of Graz, Graz, Austria
}

Received December 1, 2017

Accepted May 28, 2018

\section{Summary}

The first trimester of pregnancy is characterized by continuous proliferation, invasion and differentiation of cytotrophoblasts. These processes are precisely controlled both, in space and time by molecules such as endothelin-1 (ET-1). ET-1 is expressed in human first trimester trophoblast and is known to stimulate cytotrophoblast proliferation through endothelin $A$ and $B$ receptor subtypes $\left(\mathrm{ET}_{\mathrm{A}}\right.$ and $\left.\mathrm{ET}_{\mathrm{B}}\right)$, and cytotrophoblast invasion through $\mathrm{ET}_{\mathrm{B}}$. However, temporal changes of the ET system during the first trimester of pregnancy have not been previously studied. This study tested the hypothesis that ET-1 release, $\mathrm{ET}_{\mathrm{A}}$ and $\mathrm{ET}_{\mathrm{B}}$ expression are increased towards the end of the first trimester of pregnancy (weeks 10-12 vs. weeks 6-9), resulting in increased cytotrophoblast proliferation and invasion. Tissue samples were obtained from 17 surgical pregnancy interruptions (week 6-9: $\mathrm{n}=9$; week 10-12: $\mathrm{n}=8$ ). After cytotrophoblast isolation, the invasive and proliferative phenotypes were immune-separated by an $a_{6}$-integrin antibody. Both proliferative and invasive cytotrophoblasts were cultured separately on plastic or Matrigel for $24 \mathrm{~h}$. ET-1 release into the culture medium of both cytotrophoblast subtypes was measured by radioimmunoassay. $\mathrm{ET}_{\mathrm{A}}$ and $\mathrm{ET}_{\mathrm{B}}$ mRNA expression was measured by RT-PCR, and the ET-1 effect on cytotrophoblast proliferation and invasion was determined using proliferation and invasion assays, respectively. ET-1 release increased from early to late first trimester of pregnancy in both proliferative (1.8-4.5 fold) and invasive cytotrophoblasts (9.3-28 fold), especially when cultured on Matrigel. This was paralleled by less $\mathrm{ET}_{\mathrm{B}}$ mRNA on invasive cytotrophoblasts independent of the time period in first trimester, whereas $\mathrm{ET}_{\mathrm{A}}$ expression was similar on proliferative an invasive cytotrophoblasts. Proliferation and invasion of cytotrophoblasts under control conditions decreased from early to late first trimester. ET-1 stimulated both processes at both periods with the most pronounced effect (7-fold) on invasion in late first trimester. The ET-1/ET-receptor system changes between weeks 6-9 and 10-12 in pregnancy. Our data suggest an autocrine and endocrine ET-1 effect, which is stronger in late than in early first trimester of pregnancy paralleled by different stimulatory effects on trophoblast invasion and proliferation. In general, this suggests time as an additional effector of the critical processes governing placental development in the first trimester of human pregnancy.

\section{Key words}

Endothelin-1 - First trimester trophoblast - Proliferation • Invasion

\section{Corresponding author}

M. Cervar-Zivkovic, Department of Obstetrics and Gynecology, Medical University of Graz, Auenbruggerplatz 14, A-8036 Graz, Austria. Fax: 0043/316/385/14189. E-mail: mila.cervarzivkovic@medunigraz.at

\section{Introduction}

The human placenta is located between the maternal and fetal circulation and represents a key organ for fetal development (Desoye and Shafrir 1994). The trophoblast compartment represents the interface between the placenta and the maternal blood and tissue. It comprises the syncytiotrophoblast, a continuous epithelium harboring placental key functions such as endocrine, metabolic and transport activities, and the cytotrophoblast. Based on their prevailing biological function, two cytotrophoblast phenotypes have been identified, i.e. proliferative and invasive cytotrophoblast 
(Knofler and Pollheimer 2013). Proliferative cytotrophoblast comprises the placental villi and can fuse to form the syncytiotrophoblast. Invasive trophoblast migrate and invade the uterine decidua and spiral arteries, anchoring the placenta in the uterus and opening the spiral artery lumen (Chen J.Z. et al. 2012). The remodeling of the spiral arteries occurs around week 10 of gestation, allowing adequate blood supply to the fetus, which is paralleled by an increase in the oxygen tension in the intervillous space (Whitley and Cartwright 2010). Thus, the placenta, its maternal environment and the biological processes associated to them undergo profound changes along the first trimester of pregnancy (GoldmanWohl and Yagel 2002, Fryer and Simon 2006).

The endothelins (ETs) are a family of three polypeptides (ET-1, ET-2, ET-3), which are present in the placenta already at week 7 of gestation (Jauniaux et al. 2000). Together with the two G-protein-coupled membrane receptors, $\mathrm{ET}_{\mathrm{A}}$ and $\mathrm{ET}_{\mathrm{B}}$, the ETs form an autocrine, paracrine and endocrine system. Although ET-1 has been initially identified as regulator of the vascular tone, it exerts other cellular functions. In the human placenta we have demonstrated that ET-1 regulates cell proliferation, invasion and apoptosis, the specific effects depending on the period of gestation and the cell type. At term of gestation cytotrophoblasts secrete ET-1 (Cervar et al. 1996a) and express both $\mathrm{ET}_{\mathrm{A}}$ and $\mathrm{ET}_{\mathrm{B}}$ receptors (Cervar et al. 2000). This allows an autocrine/paracrine ET-1 action, protecting cytotrophoblasts from apoptosis through $\mathrm{ET}_{\mathrm{B}}$ receptor activation (Cervar-Zivkovic et al. 2007).

In the first trimester of pregnancy, ET-1 stimulates trophoblast proliferation and invasion in vitro in a receptor subtype-specific manner, with $\mathrm{ET}_{\mathrm{A}}$ being present predominantly on proliferative cytotrophoblasts, whereas $\mathrm{ET}_{\mathrm{B}}$ can be found on both cytotrophoblast subpopulations (Cervar et al. 1996b, Cervar-Zivkovic et al. 2011). Cytotrophoblast proliferation and invasion are critical for a successful pregnancy, and their impairment has been linked to certain pregnancy complications such as in preeclampsia, gestational diabetes and miscarriages, where the ET system has also been implicated (Khong et al. 1992, Brosens et al. 2002, Dieber-Rotheneder et al. 2006, Dieber-Rotheneder et al. 2012, Cervar et al. 1995, Cervar and Desoye 1998). However, the temporal regulation of the ET system along the first trimester of pregnancy remains unknown.

The present study tested the hypothesis that the ET-system undergoes temporal changes in the first trimester of human pregnancy and that the pattern of these changes differs between both cytotrophoblast subpopulations, i.e. proliferative and invasive cytotrophoblast. The specific aim of the study was to investigate whether ET-1 release and ET-1 receptor expression are increased towards the end of the first trimester of human pregnancy (weeks 10-12), and to test for their functional consequences.

\section{Methods}

The study was approved by the ethical committee of the Medical University of Graz (approval No. 12-095). Signed informed consent was obtained from the pregnant women.

\section{Isolation of cytotrophoblast subpopulations}

Cytotrophoblast cells were isolated from 17 placentas obtained after legal abortions performed for psychosocial reasons between weeks 6-12 of gestation. Gestational age was determined by measuring the crown rump length in the first trimester of gestation. After the standard cell isolation procedure using enzyme digestion and Percoll-gradient separation as described previously (Cervar et al. 1996a, Cervar et al. 1999), the common leukocyte antigen expressing cells (20-30\% of cells) were incubated with $30 \mu \mathrm{l}$ of an anti-CD45RB monoclonal antibody (Dako, Glostrup, Germany) for $30 \mathrm{~min}$ at $4{ }^{\circ} \mathrm{C}$ with gentle swirling. After incubation, the cells were washed with PBS containing $0.1 \%$ bovine serum albumin (Sigma-Aldrich, Vienna, Austria). Magnetic particles coated with goat anti-mouse IgG-antibody (30 $\mu 1$ Dynabeads M-450; Dynal, Oslo, Norway) were incubated with the cell suspension for $20 \mathrm{~min}$ at $4{ }^{\circ} \mathrm{C}$ with gentle swirling. A magnet was applied along the test tube to retain the particles bound to the cells expressing CD45RB on their surface. About five million cells were obtained from $2-4 \mathrm{~g}$ placental tissue after initial immunopurification with CD45RB antibody.

Proliferative and invasive cytotrophoblasts were separated based on their surface $\alpha_{6}$ integrin expression. The cells in the proximal part of the trophoblast cell column express $\alpha_{6}$ integrin and were considered proliferative, and those devoid of integrin $\alpha_{6}$ were regarded as representing the invasive phenotype and to originate from the more distal part of the trophoblast cell column (Cervar-Zivkovic et al. 2011). In order to separate the proliferative and invasive trophoblast cells, the purified cytotrophoblasts were incubated for $30 \mathrm{~min}$ 
at $4{ }^{\circ} \mathrm{C}$ with $30 \mu \mathrm{l}$ of a mouse anti-CD49f monoclonal antibody (clone VLA6, Immunotech, Marseille, France) directed against integrin $\alpha_{6}$ (Khong et al. 1992). As described above, the cells expressing $\alpha_{6}$ integrin on their surface were separated using a magnet and further detached from the beads using an acid wash in bicarbonate buffer ( $\mathrm{pH} 5.5$ ).

\section{Cell characterization}

Aliquots of the cell suspensions $(0.1 \mathrm{ml}$ containing $10^{4}$ cells) were cultured on chamber glass slides (Nunc, Naperville, Illinois, USA) with DMEM. After $24 \mathrm{~h}$, cells adhering to the coverslips were washed in PBS, pH 7.2, for $5 \mathrm{~min}$. Cells were incubated with the following monoclonal primary antibodies, which were diluted in PBS containing 0.1 \% BSA: anti-cytokeratin 7 to identify trophoblastic cells (1:50; Monosan, Uden, Netherlands), anti-CD45RB (1:50; Monosan, Uden, Netherlands) to recognize the leukocyte common antigen, anti-CD49a-FITC conjugate (1:100; Serotec, Kidlington, UK) to identify $\alpha_{1}$ integrin positive cells, anti-CD49eFITC conjugate $\left(1: 20\right.$; Serotec) for $\alpha_{5}$ integrin positive cells, and anti-CD49f-FITC conjugate (1:50; Serotec) for $\alpha_{6}$ integrin positive cells. Antibody incubation was followed by three washing-steps in PBS, pH 7.2. Subsequent to the staining with anti-cytokeratin 7 and anti-CD45RB, a 30 min incubation with a goat anti-mouse secondary antibody (FITC-conjugated, 1:20; Dianova, Hamburg, Germany) was performed. Cells were counted in 10 random fields at a magnification of $400 \mathrm{X}$ using a light and fluorescence microscope Axioplan (Zeiss, Oberkochen, Germany) with Axiovision 4.6 software.

After immunopurification with anti-CD45RB antibodies more than $99 \%$ cells reacted with anticytokeratin 7 antibodies (trophoblast cells) and $<1 \%$ with anti-CD45RB antibodies (myeloid origin). After the subsequent immunoseparation with the integrin $\alpha_{6}$ antibody, $99 \%$ of proliferative and $<1 \%$ of invasive cells were $\alpha_{6}$ positive.

\section{Cell culture}

The separated $\alpha_{6}$ integrin positive (proliferative) and $\alpha_{6}$ integrin negative (invasive) cells were washed with PBS containing $0.1 \%$ bovine serum albumin. Subsequently, proliferative and invasive cytotrophoblast were plated on plastic or growth factor reduced Matrigel (Becton Dickinson, Laevosan, Linz, Austria), respectively. Matrigel is a common extracellular matrix used to ensure that invasive cytotrophoblast retain their phenotype in culture (Tarrade et al. 2002). Both proliferative and invasive cells were cultured in DMEM without FCS in a humidified incubator at $5 \%$ carbon dioxide and $37^{\circ} \mathrm{C}$. After $24 \mathrm{~h}$, the media were collected and the cells removed in PCR buffer and stored at $-80^{\circ} \mathrm{C}$ until analysis.

\section{ET-1 release}

The concentration of ET-1 in the culture medium was measured in triplicate by a commercially available radioimmunoassay (Amersham, Little Chelfont, UK) with the following performance characteristics: intra-assay coefficient of variation $<7.2 \%$, inter-assay coefficient of variation $<4.6 \%$, cross-reactivity $<0.001 \%$ with endothelin-3, $<0.003 \%$ with big endothelin; sensitivity $2 \mathrm{fmol} / \mathrm{ml}$. The ET-1 concentration in medium without cells was below the detection limit of the assay. Results were expressed as pg of ET- 1 secreted per $10^{6}$ cells.

\section{RT-PCR}

\section{RNA isolation and amplification}

The PCR reaction mix was overlaid with mineral oil and kept on ice until the thermal cycler reached $95^{\circ} \mathrm{C}$. After denaturation at $95^{\circ} \mathrm{C}$ for $120 \mathrm{~s}$ samples were subjected to 25 cycles of PCR amplification. Each cycle consisted of a $30 \mathrm{~s}$ denaturation at $94{ }^{\circ} \mathrm{C}$, a $30 \mathrm{~s}$ annealing at $55^{\circ} \mathrm{C}$ and a $60 \mathrm{~s}$ extension at $72^{\circ} \mathrm{C}$. Ten $\mu 1$ of each PCR reaction mixture were separated by electrophoresis on $3 \%$ agarose gels (Metaphor agarose, FMC BioProducts, Rockland, ME, USA) in Tris borate/EDTA buffer, stained with ethidium bromide, visualized by UV-irradiation and photographed.

\section{Quantitative analysis}

Ethidium fluorescence associated with the DNA bands in the gel was quantitated using a working station including a UV transilluminator light box, a high speed video camera (Hitachi, Vienna, Austria) connected directly to a computer-based system for data analysis and storage (Elscript software, Hirschmann, Munich, Germany) and an attached video printer for hardcopy output (Mitsubishi, Vienna, Austria).

\section{Validation of the assay}

To determine the ET-receptor mRNA content in different tissue samples, values of ET-receptor mRNA were normalized to values of ribosomal RPL30 mRNA as an internal standard.

The absence of contaminants was verified in 
control experiments omitting RNA. In addition, in order to test for the absence of genomic DNA control RT-PCR reactions were carried out without adding the enzyme during the RT step. All results were discarded when unspecific bands, in addition to the expected ones, were visible on the agarose gel. Cycle titration demonstrated that for both, RPL30 mRNA and ET-receptor mRNA, 25 cycles lay within the linear phase of PCR-amplification.

\section{Proliferation and invasion assay}

The $\alpha_{6}$ integrin positive cells, i.e. proliferative cytotrophoblasts, were plated on uncoated polycarbonate cell culture inserts $(0.45 \mu \mathrm{m})$ in 24-well culture plates $\left(1 \times 10^{3}\right.$ cells/well $)$ containing $500 \mu \mathrm{l}$ of Dulbecco's Modified Eagle's Medium (DMEM) with $10 \mu \mathrm{Ci}$ $\left[{ }^{3} \mathrm{H}\right]-5$-methyl-thymidine (Amersham Pharmacia Biotech, Little Chalfont, UK). Cells were incubated in the absence or the presence of $10 \mathrm{nmol} / \mathrm{ml}$ ET-1. After $24 \mathrm{~h}$ the inserts were washed twice in PBS, placed in a vial, and counted in a Beckman scintillation counter to determine associated radioactivity. Inserts incubated without cells were used to determine blank values (Cervar-Zivkovic et al. 2011).

The integrin $\alpha_{6}$ negative cells, i.e. invasive cytotrophoblasts, were plated on 24-well BioCoat Matrigel invasion chambers (Becton Dickinson, Laevosan, Linz, Austria) and incubated in DMEM with $10 \mu \mathrm{Ci}\left[{ }^{3} \mathrm{H}\right]-5$-methylthymidine for $24 \mathrm{~h}$, with the same concentration of ET-1 and the same cell density as described above. After the incubation period, the media were collected from the upper and lower wells. The cells were scraped from the upper side of the membrane separating both compartments and added to the respective medium. The membrane with the cells attached underneath was added to the medium from the lower well. Radioactive disintegrations were measured with a scintillation counter and the invasion index (lower well radioactivity/total well activity $\mathrm{x} 100$ ) was calculated (Cervar-Zivkovic et al. 2011). This method allowed controlling for the ET-1 induced change in cytotrophoblast number.

\section{Statistics}

Data are presented as mean \pm SEM of $n=5$ isolations per time period unless stated otherwise. Each experiment was run in 3 technical triplicates. Significance of differences was tested using non-parametric Mann Whitney U-test with $\mathrm{p} \leq 0.05$ accepted as significant.

\section{Results}

\section{Release of ET-1}

ET-1 release was influenced by the extracellular matrix, the cell phenotype and the week of gestation. When compared with the same cell type cultured on plastic, Matrigel induced a significant increase of ET-1 secretion in proliferative cytotrophoblast from weeks $10-12(\mathrm{p}<0.001)$ and in invasive cytotrophoblast from weeks 6-9 and 10-12 (p<0.05) (Fig. 1).

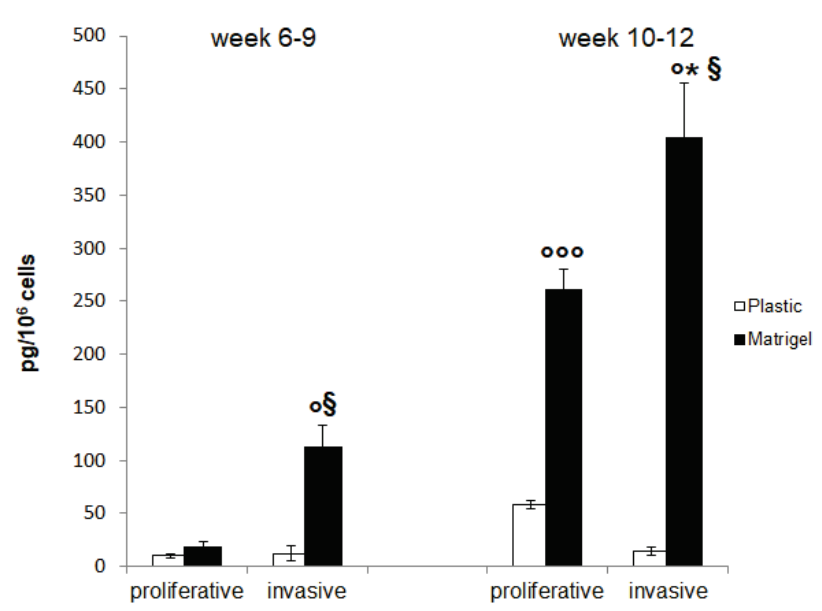

Fig. 1. Release of ET-1 into the culture medium from human first trimester proliferative and invasive cytotrophoblast (CT) cells ( $10^{6}$ cells/well; $n=5$ isolations) cultured for $24 \mathrm{~h}$ on plastic or Matrigel. ${ }^{\circ} p<0.05,{ }^{\circ 0} p<0.001$, vs. plastic, ${ }^{*} p<0.01$ vs. $6-9$ weeks, ${ }^{\S} p<0.01$ vs. proliferative cytotrophoblast.

A direct comparison between both cell phenotypes, i.e. proliferative and invasive cytotrophoblast, showed that invasive cells secrete a higher amount of ET-1 than proliferative cells only when cultured on Matrigel (Fig. 1; proliferative vs. invasive; $p<0.01)$. These differences were independent of the week of gestation. No differences on ET-1 release were found between proliferative and invasive cytotrophoblast cultured on plastic.

Finally, when comparing proliferative and invasive cytotrophoblast from different weeks of gestation (i.e. weeks 6-9 vs. weeks 10-12), we found an increase of ET-1 release in both proliferative and invasive cytotrophoblast from weeks 10-12, although only the latter reached significance. Again, these differences were only observed when the cells were cultured on Matrigel.

\section{Expression of endothelin receptors}

ET-A mRNA expression was similar in proliferative and invasive cytotrophoblasts at both time 
periods, suggesting that gestational age had no significant effect on ET-A mRNA levels (Fig. 2a). There was a tendency for lower ET-B mRNA levels in invasive cytotrophoblast in comparison with proliferative cytotrophoblasts, but data variation precluded the significance in the latter. The time period did not have a significant effect on ET-B mRNA levels (Fig. 2b). Combining ET-B mRNA data from weeks 6-9 with those of weeks 10-12 showed time-independent lower ET-B mRNA levels in invasive compared to proliferative cytotrophoblasts $(\mathrm{p} \leq 0.05)$.

a
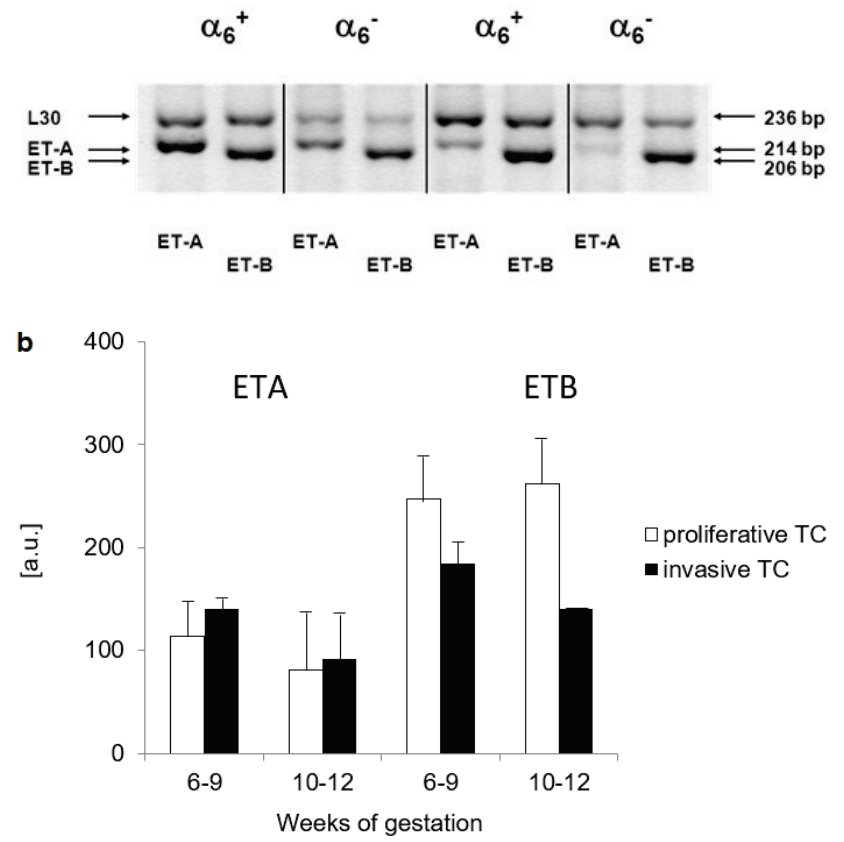

Fig. 2. Expression of ET receptor mRNA in human first trimester cytotrophoblast. Proliferative and invasive cytotrophoblast $(n=5$ isolations) were cultured on plastic or Matrigel, respectively, and ET receptor expression was measured after $24 \mathrm{~h}$. a) Representative examples of endothelin receptor mRNA expression blots at weeks 8 and 12 of gestation. b) Quantitative analysis performed by densitometry. ${ }^{\circ} \mathrm{p}<0.01$ vs. proliferative cytotrophoblasts week $10-12,{ }^{*} p<0.01$ vs. 6-9 weeks.

\section{The effect of ET-1 on proliferation and invasion}

Cytotrophoblast proliferation and invasion were measured on cells cultured on plastic and Matrigel, respectively. Cell proliferation and invasion decreased with gestational age (Fig. 3 and Fig. 4; p<0.01). This decrease was observed in both the untreated control group and in those cells incubated with $10 \mathrm{nM} / \mathrm{ml}$ ET-1.

Exogenous ET-1 stimulated proliferation at both periods of gestation, with an increase of $54 \pm 10 \%$ at weeks $6-9$ and $70 \pm 14 \%$ at weeks $10-12$, respectively (Fig. $3 ; \mathrm{p}<0.01$ vs. control). The stimulatory effect of
ET-1 on cytotrophoblast invasion was dependent on weeks of gestation, being stronger at weeks 10-12 (7-fold increase) than at weeks 6-9 (20 $\pm 11 \%$ increase) (Fig. 4; $\mathrm{p}<0.01$ vs. control).

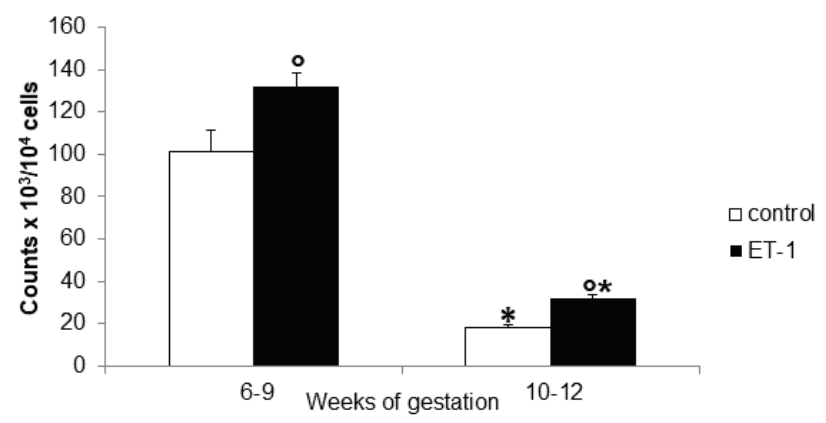

Fig. 3. Effect of ET-1 on cytotrophoblast proliferation. Proliferative human first trimester cytotrophoblast $(n=4$ isolations) were cultured on plastic and incubated in the absence (control) or presence of $10 \mathrm{nmol} / \mathrm{ml} \mathrm{ET}-1$ for $24 \mathrm{~h}$. Cell proliferation was expressed as the number of radioactivity counts per $10^{4}$ cells. ${ }^{\circ} p<0.01$ vs. control, ${ }^{*} p<0.01$ vs. $6-9$ weeks.

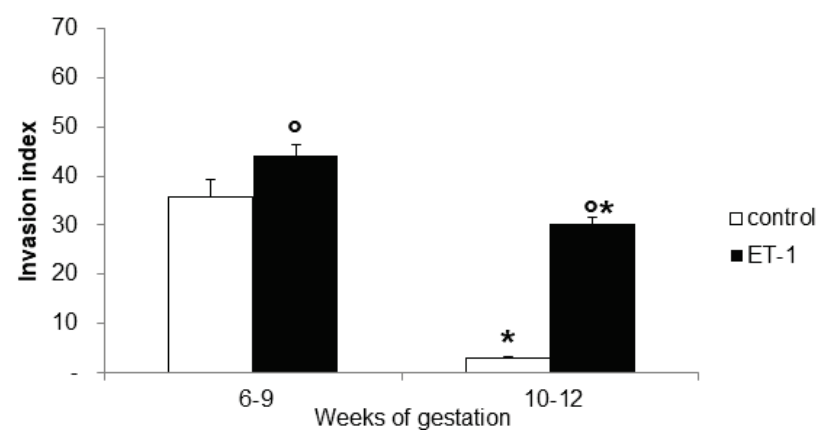

Fig. 4. Effect of ET-1 cytotrophoblast invasion. Invasive human first trimester cytotrophoblast ( $n=3$ isolations) were cultured on Matrigel and incubated in the absence (control) or presence of $10 \mathrm{nmol} / \mathrm{ml} \mathrm{ET}-1$ for $24 \mathrm{~h}$. Results were expressed as the cell invasion index. ${ }^{\circ} p<0.01$ vs. control, ${ }^{*} p<0.01$ vs. $6-9$ weeks.

\section{Discussion}

The present study investigated the temporal changes in the endothelin system and two of its key functions, i.e. regulation of cell proliferation and invasion, during early and late first trimester of pregnancy in the two different cytotrophoblast populations, i.e. proliferative and invasive cytotrophoblast. These phenotypes were isolated based on their surface $\alpha_{6}$ integrin expression. The separate analysis of these two cytotrophoblast subtypes is a major strength of this study.

Three key results were found. First of all, the characteristic intrinsic properties of first trimester human cytotrophoblasts, i.e. proliferation and invasion, are not stable over the period between week 6 to week 12 
of gestation. Under control conditions cytotrophoblast is only exposed in an autocrine manner to the intrinsically produced growth factors and cytokines, among which ET-1 is one component (Cervar et al. 1996b, CervarZivkovic et al. 2011). The weaker cytotrophoblast invasion late in first trimester is in line with the reduction of $\mathrm{ET}_{\mathrm{B}}$ mRNA levels, which is the ET receptor subtype involved in cytotrophoblast invasion (Cervar-Zivkovic et al. 2011). Thus, our data suggest that the down-regulation of $\mathrm{ET}_{\mathrm{B}}$ expression could not be compensated by an increase of ET-1 secretion. Nevertheless, other mechanisms governing trophoblast invasion, i.e. a diminished activity of invasion promoting molecules or the secretion of anti-invasive factors, should be considered (Knofler and Pollheimer 2013).

Second, exogenous ET-1 increases human first trimester cytotrophoblast proliferation and invasion. In vivo, the source of ET-1, which govern cytotrophoblast functions, may be either the cytotrophoblast or cells of the maternal endometrium (Cameron et al. 1995), thus representing a paracrine and/or autocrine system. It may participate in local events, controlling mesenchymalepithelial interactions during implantation and trophoblast invasion. The exogenous supply of ET-1 in this study aims to mimic the paracrine effect of ET-1 on first trimester cytotrophoblast in vitro. In our study, the stimulatory effect of ET-1 on cytotrophoblast proliferation and invasion was stronger in late first trimester cytotrophoblast. This suggests an important role of both paracrine and autocrine ET-1, since ET-1 secretion is increased in late first trimester cytotrophoblast. Moreover, this effect might be also associated with the differential $\mathrm{ET}_{\mathrm{B}}$ receptor expression in early vs. late first trimester cytotrophoblasts.

Third, Matrigel modifies ET-1 secretion. Although a detailed analysis of the effect of extracellular matrix was outside the scope of this study, the data demonstrate a link between extracellular matrix and ET-1 secretion. This may suggest an involvement of the integrin-focal adhesion kinase complex on ET-1 secretion (Haneda et al. 1995). However, although growth factorreduced Matrigel was used in the study, traces of growth factors are still present and their contribution cannot be fully ruled out.

The specific mechanisms accounting for the temporal expression changes are unknown. The proximal promoter of ET-1 and $\mathrm{ET}_{\mathrm{B}}$ harbor hypoxia response elements (Minchencko et al. 2000) and may thus be regulated by changes in ambient oxygen as they occur between weeks 8 and 10 of gestation, which are the gestational periods studied here. Alternative mechanisms could involve microRNA-199 and/or microRNA-155 (Yeligar et al. 2009). The latter seems an attractive hypothesis warranting further investigations, because microRNA-155 inhibits proliferation and migration of extravillous cytotrophoblast cell models (Dai et al. 2012). The contribution of shear-stress regulated transcription factors is a further potential mechanism.

The results presented here have important implications. Trophoblast invasion is limited in time and space and regulated by at least metalloproteinases 2, 9, 14 and 15 (Cohen et al. 2010, Majali-Martinez et al. 2016), several cytokines (TGF- $\beta$, TNF- $\alpha$, IFN- $\gamma$ ) (Otun et al. 2011, Prutsch et al. 2012), growth factors (HB-EGF, EG-VEGF, leptin) (Chen Y. et al. 2012, Brouillet et al. 2013, Chen et al. 2011) and hormones (HCG, progesterone, estrogen, leptin) (Chen J.Z. et al. 2012, Goldman-Wohl and Yagel 2002, Chen et al. 2011, Liu et al. 2009). However, these studies have not distinguished between several periods in the first trimester. Therefore, it cannot be ruled out that some of these factors may have other effects, if any at all, at different periods in the first trimester. Moreover, results obtained with first trimester trophoblast primary isolations and cell lines often represent only one stage of first trimester and generalizations for the whole period of first trimester of pregnancy have to be made with caution.

\section{Conclusion}

The present study provides the first evidence that the ET-1/ET-receptor system governs trophoblast invasion and proliferation in a temporal manner in addition to its spatially restricted regulation (CervarZivkovic et al. 2011, Thaete et al. 2007). Thus, the present study adds time in gestation as a further layer of regulation of the endothelin system in human cytotrophoblast, allowing the fine tuning of its special functions in early placental development. Disturbances of this system may contribute to the etiology of pregnancy complications associated with impaired cytotrophoblast invasion or proliferation (Khong et al. 1992, DieberRotheneder et al. 2006). The clear influence of gestational age in the first trimester of two processes essential for establishing and maintaining a successful pregnancy has important implications for our understanding and will stimulate new studies in this area of research. 


\section{Limitations}

Some limitations of the study need to be acknowledged. We have aimed for highly purified cytotrophoblast subpopulations. As the quality controls demonstrated this was successfully achieved but at the cost of yield. The low number of cells did not permit carrying out additional protein studies with the same preparations used for the functional assays. Thus, the ET receptor data are limited to the transcript level. Moreover, in vivo the oxygen tension rises in the intervillous space between weeks 6 and 12 of pregnancy from $2.5-6.5 \% \mathrm{O}_{2}$ to $8 \% \mathrm{O}_{2}$ (Rodesch et al. 1992). This situation was not mimicked in our experiments, which were performed only under $20 \% \mathrm{O}_{2}$. Oxygen tension is a classical regulator of gene expression (Fryer and Simon 2006), including ET-1 (Stow et al. 2011) and $\mathrm{ET}_{\mathrm{B}}$ expression (Jain et al. 2012). Although this was out of the scope of the present study, further investigation about the role of oxygen in the regulation of the ET system in the first trimester of pregnancy is warranted.

\section{Conflict of Interest}

There is no conflict of interest.

\section{Acknowledgements}

The authors are indebted to the expert technical assistance of Renate Michlmaier. This study was supported by Grant Nr. 12243 of the Jubilee Fund, Austrian National Bank, Vienna.

\section{References}

BROSENS JJ, PIJNENBORG R, BROSENS IA: The myometrial junctional zone spiral arteries in normal and abnormal pregnancies: a review of the literature. Am J Obstet Gynecol 187: 1416-1423, 2002.

BROUILLET S, MURTHI P, HOFFMANN P, SALOMON A, SERGENT F, DE MAZANCOURT P, DAKOUANEGIUDICELLI M, DIEUDONNÉ MN, ROZENBERG P, VAIMAN D, BARBAUX S, BENHAROUGA M, FEIGE JJ, ALFAIDY N: EG-VEGF controls placental growth and survival in normal and pathological pregnancies: case of fetal growth restriction (FGR). Cell Mol Life Sci 70: 511-525, 2013.

CAMERON IT, BACON CR, COLLET GP, DAVENPORT AP: Endothelin expression in the uterus. J Steroid Biochem Mol Biol 53: 209-214, 1995.

CERVAR M, DESOYE G: The endothelin/endothelin receptor system of human trophoblast in normal and preeclamptic pregnancies. Troph Res 12: 341-357, 1998.

CERVAR M, BLASCHITZ A, DOHR G, DESOYE G: Paracrine regulation of distinct trophoblast functions in vitro by placental macrophages. Cell Tissue Res 295: 297-305, 1999.

CERVAR M, KAINER F, DESOYE G: Preeclampsia and gestational age differently alter binding of endothelin-1 to placental and trophoblast membrane preparations. Mol Cell Endocrinol 110: 65-71, 1995.

CERVAR M, KAINER F, JONES CJP, DESOYE G: Altered release of endothelin-1,2, and thromboxane B2 from trophoblastic cells in preeclampsia. Eur J Clin Invest 26: 30-37, 1996a.

CERVAR M, PUERSTNER P, KAINER F, DESOYE G: Endothelin-1 stimulates the proliferation and invasion of first trimester trophoblast cells in vitro - a possible role in the etiology of preeclampsia? J Invest Med 44: 447-453, $1996 \mathrm{~b}$.

CERVAR M, HUPPERTZ B, BARTH S, HAHN T, WEISS U, KAUFMANN P, DESOYE G: Endothelin A and B receptors change their expression levels during development of human placental villi. Placenta 21: 536-546, 2000.

CERVAR-ZIVKOVIC M, HU C, BARTON A, SADOVSKY Y, DESOYE G, LANG U, NELSON DM: Endothelin-1 attenuates apoptosis in cultured trophoblasts from term human placentas. Reprod Sci 14: 430-440, 2007.

CERVAR-ZIVKOVIC M, DIEBER-ROTHENEDER M, BARTH S, HAHN T, KOHNEN G, HUPPERTZ B, LANG U, DESOYE G: Endothelin-1 stimulates the invasion of first trimester trophoblast specifically via the B-type receptor, whereas its action on proliferation is mediated by both receptor subtypes. J Clin Endocrin Metab 96: 3408-3415, 2011.

CHEN JZ, WONG MH, BRENNECKE SP, KEOGH RJ: The effects of human chorionic gonadotrophin, progesterone and oestradiol on trophoblast function. Mol Cell Endocrinol 342: 73-80, 2011. 
CHEN JZ, SHEEHAN PM, BRENNECKE SP, KEOGH RJ: Vessel remodelling, pregnancy hormones and extravillous trophoblast function. Mol Cell Endocrinol 349: 138-144, 2012.

CHEN Y, WU XX, TAN JP, LIU ML, LIU YL, ZHANG JP: Effects of low molecular weight heparin and heparinbinding epidermal growth factor on human trophoblast in first trimester. Fertil Steril 97: 764-770, 2012.

COHEN M, WUILLEMIN C, IRION O, BISCHOF P: Role of decidua in trophoblastic invasion. Neuro Endocrinol Lett 31: 193-197, 2010.

DAI Y, QIU Z, DIAO Z, SHEN L, XUE P, SUN H, HU Y: MicroRNA-155 inhibits proliferation and migration of human extravillous trophoblast derived HTR-8/SVneo cells via down-regulating cyclin D1. Placenta 33: 824-829, 2012.

DESOYE G, SHAFRIR E: Placental metabolism and its regulation in health and diabetes. Mol Aspects Med 15: 505-682, 1994.

DIEBER-ROTHENEDER M, STERN C, DESOYE G, CERVAR-ZIVKOVIC M: Up-regulation of the endothelin receptor A in placental tissue from first trimester delayed miscarriages. J Soc Gynecol Investig 13: 435-441, 2006.

DIEBER-ROTHENEDER M, BEGANOVIC S, DESOYE G, CERVAR-ZIVKOVIC M: Endothelin/endothelin receptor system is upregulated in preeclampsia with or without fetal growth restriction in contrast to gestational diabetes. Life Sci 91: 710-715, 2012.

FRYER BH, SIMON MC: Hypoxia, HIF and the placenta. Cell Cycle 5: 495-498, 2006.

GOLDMAN-WOHL D, YAGEL S: Regulation of trophoblast invasion: from normal implantation to preeclampsia. $M o l$ Cell Endocrinol 187: 233-238, 2002.

HANEDA M, KIKKAWA R, KOYA D, SHIKANO T, SUGIMOTO T, TOGAWA M, SHIGETA Y: Endothelin-1 stimulates tyrosine phosphorylation of p125 focal adhesion kinase in mesangial cells. J Am Soc Nephrol 6: 1504-1510, 1995.

JAIN A, OLOVSSON M, BURTON GJ, YUNG HW: Endothelin-1 induces endoplasmic reticulum stress by activating the PLC-IP(3) pathway: implications for placental pathophysiology in preeclampsia. Am J Pathol 180: 2309-2320, 2012.

JAUNIAUX E, MIGNOT TM, REBOURCET R, ROBERT B, FERRÉ F: Placental endothelin gene expression and endothelin concentration in fetal fluids of the first trimester gestational sac. Mol Hum Reprod 6: 758-762, 2000.

KHONG TY, SAWYER IH, HERYET AR: An immunohistologic study of endothelialisation of uteroplacental vessels in human pregnancy - evidence that endothelium is focally disrupted by trophoblast in preeclampsia. Am J Obstet Gynecol 167: 751-756, 1992.

KNOFLER M, POLLHEIMER J: Human placental trophoblast invasion and differentiation: a particular focus on Wnt signaling. Front Genet 4: 190, 2013.

LIU H, WU Y, QIAO F, GONG X: Effect of leptin on cytotrophoblast proliferation and invasion. J Huazhong Univ Sci Technolog Med Sci 29: 631-636, 2009.

MAJALI-MARTINEZ A, HIDEN U, GHAFFARI-TABRIZI-WIZSY N, LANG U, DESOYE G, DIEBERROTHENEDER M: Placental membrane-type metalloproteinases (MT-MMPs): key players in pregnancy. Cell Adh Migr 10: 136-146, 2016.

MINCHENCKO A, CARO J: Regulation of endothelin-1 gene expression in human microvascular endothelial cells by hypoxia and cobalt: role of hypoxia responsive element. Mol Cel Biochem 208: 53-62, 2000.

OTUN HA, LASH GE, INNES BA, BULMER JN, NARUSE K, HANNON T, SEARLE RF, ROBSON SC: Effect of tumour necrosis factor- $\alpha$ in combination with interferon- $\gamma$ on first trimester extravillous trophoblast invasion. J Reprod Immunol 88: 1-11, 2011.

PRUTSCH N, FOCK V, HASLINGER P, HAIDER S, FIALA C, POLLHEIMER J, KNÖFLER M: The role of interleukin-1 $\beta$ in human trophoblast motility. Placenta 33: 696-703, 2012.

RODESCH F, SIMON P, DONNER C, JAUNIAUX E: Oxygen measurements in endometrial and trophoblastic tissues during early pregnancy. Obstet Gynecol 80: 283-285, 1992.

STOW LR, JACOBS ME, WINGO CS, CAIN BD: Endothelin-1 gene regulation. FASEB J 25: 16-28, 2011. 
TARRADE A, GOFFIN F, MUNAUT C, LAI-KUEN R, TRICOTTET V, FOIDART JM, VIDAUD M, FRANKENNE F, EVAIN-BRION D: Effect of matrigel on human extravillous trophoblasts differentiation: modulation of protease pattern gene expression. Biol Reprod 67: 1628-1637, 2002.

THAETE LG, JILLING T, SYNOWIEC S, KHAN S, NEERHOF MG: Expression of endothelin 1 and its receptors in the hypoxic pregnant rat. Biol Reprod 77: 526-532, 2007.

WHITLEY GS, CARTWRIGHT JE: Cellular and molecular regulation of spiral artery remodelling: lessons from the cardiovascular field. Placenta 31: 465-474, 2010.

YELIGAR S, TSUKAMOTO H, KALRA VK: Ethanol-induced expression of ET-1 and ET-BR in liver sinusoidal endothelial cells and human endothelial cells involves hypoxia-inducible factor-1 $\alpha$ and microRNA-199. J Immunol 183: 5232-5243, 2009. 